with Cushing's syndrome and Addison's disease are similar to those in healthy control subjects. ${ }^{11}$ The number of glucocorticoid receptors in lymphocytes is, however, significantly reduced in patients with anorexia nervosa. ${ }^{12}$ Although dietary restrictions cannot be excluded as a possible cause of the reduced number of receptors in anorexia nervosa and in some cases of depression, it is equally plausible that the similar decline in the numbers of receptors in both conditions points to a biological link between them.

Resistance to glucocorticoids in man and other species is associated with a decrease in the number of glucocorticoid receptors in lymphoid tissue ${ }^{13}{ }^{14} ;$ this might also explain why the clinical features of hypercortisolaemia are usually absent in severe depression and anorexia nervosa. Resistance to glucocorticoids in depression may also be related to changes in the function of glucocorticoid receptors; this is suggested by the fact that the absence of cortisol suppression in response to dexamethasone in depression is associated with a failure of dexamethasone to decrease the immunoproliferative response to mitogens in the same patients. ${ }^{15}$

Though our results and those of Kontula et al and Lowy et al might explain the apparent resistance of depressed patients to the effects of hypercortisolaemia, ${ }^{12}{ }^{14}$ it remains a matter for speculation whether changes in peripheral glucocorticoid receptors reflect a generalised change in numbers of glucocorticoid receptors including those in the brain. If the number of receptors decreased in the hippocampus, an area of the brain associated with control of the hypothalamic pituitary adrenal system ${ }^{16}$ and in which tricyclic antidepressants affect glucocorticoid receptors, ${ }^{17}$ this could partly explain the increased output of adrenocorticotrophin and cortisol in depression.

We thank the staff at Telecommunications House, Edinburgh, for their help with this study and our colleagues in the Royal Edinburgh Hospital for allowing us to study patients under their care. We also thank Norma Brearley for the careful preparation of this manuscript.

\section{References}

1 Christie JE, Whalley LJ, Dick H, Blackwood DHR, Blackburn IM, Fink G. Raised plasma cortisol concentrations are a feature of drug-free psychotics and are not specific for depression. Brf Psychiatry 1986;148:58-65.

2 Wing JK, Cooper JE, Sartorius N. The measurement and classification of psychiatric symptoms. London: Cambridge University Press, 1974

3 Hamilton M. A rating scale for depression. I Neurol Neurosurg Psychiatry 1960;23:56-62.

4 Spitzer RL, Endicott J, Robins E. Research Diagnostic Criteria: rationale and reliability. Arch Gen Psychiatry 1978;35:773-82.

5 Boyum A. Separation of leukocytes from blood and bone marrow. Scandinavian fournal of Clinical Investigation 1968;21 (suppl 97): 1-107.

6 Scatchard G. The attractions of proteins for small molecules and ions. Ann NY Acad Sci 1949;51:660-72.

7 Seth J, Brown LM. A simple radioimmunoassay for plasma cortisol. Clin Chim Acta 1978;86: 109 20 .

8 Halbreich U, Asnis G, Shindledecker R, Zumoff B, Nathan S. Cortisol secretion in endogenous depression. II. Time-related functions. Arch Gen Psychiatry 1985;42:909-14.

9 Bar RS, Roth J. Insulin receptor status in disease states of man. Arch Intern Med 1977;137:474-9.

10 Jänne O, Kontula K, Vihko R, Feil PD, Bardin CW. Progesterone receptor and regulation of progestin action in mammalian tissues. Med Biol 1978;56:225.

1 Kontula K, Pelkonen R, Andersson L, Siuula A. Glucocorticoid receptors in adrenocorticoid disorders. 7 Clin Endocrinol Metab 1980;51:654-7.

12 Kontula K, Andersson LC, Huttenen M, Pelkonen R. Reduced level of cellular glucocorticoid receptors in patients with anorexia nervosa. Horm Metab Res 1982;14:619-20.

13 Chrousos GP, Loriaux DL, Brandon D, et al. Primary cortisol resistance: a familial syndrome and an animal model. I Steroid Biochem 1983;19:567-75.

14 Kraft N, Hodgson AJ, Funder JW. Glucocorticoid receptor and effector mechanisms: a comparison of the corticosensitive mouse with the corticoresistant guinea pig. Endocrinology 1979;104:344-9.

15 Lowy MT, Reder AT, Antel JP, Meltzer HY. Glucocorticoid resistance in depression: the dexamethasone suppression test and lymphocyte sensitivity to dexamethasone. Am f Psychiatry 1984;141:1365-7.

16 Sapolsky RM, Krey LC, McEwen BS. Glucocorticoid-sensitive hippocampal neurons are involved in terminating the adrenocortical stress response. Proc Natl Acad Sci USA 1984;81:6174-7.

17 Angelucci L, Patacchioli FR, Bohus B, De Kloet R. Serotoninergic innervation and glucocorticoid binding in the hippocampus: relevance to depression. In: Costa $\mathrm{E}$, Racagni $\mathrm{G}$, eds. Typical and binding in the hippocampus: relevance to depression. In: Costa E, Racagni G, eds. Typur

(Accepted 14 January 1986)

\title{
Role of drugs in fractures of the femoral neck
}

\author{
SAIFUDIN RASHIQ, RICHARD F A LOGAN
}

\begin{abstract}
To investigate the role of drugs in the rising incidence of fractures of the femoral neck in the elderly a case-control study inquiring about the use of prescribed drugs was carried out. The drug histories of 102 patients with femoral neck fractures were obtained from general practice records and compared with those of 204 controls matched for age and sex from the same practices. At the time of fracture 41 patients with fractures and 126 controls were receiving at least one prescription (relative risk of fracture of the femoral neck in patients taking drugs $=0.42, p=0.0006$ ). For all types of prescribed drugs except antibiotics the risk of fracture of the femoral neck was less in patients taking drugs than in those not doing so, and this was true at all times in the year before fracture. Six patients with fractures were receiving
\end{abstract}

Department of Community Health, University of Nottingham, Queen's Medical Centre, Nottingham NG7 2UH

SAIFUDIN RASHIQ, BMEDSCI, medical student

RICHARD F A LOGAN, MSC, MRCP, senior lecturer in clinical epidemiology

Correspondence to: Dr.Logan. thiazide diuretics compared with 37 controls (relative risk 0.28 , $\mathrm{p}=\mathbf{0 . 0 0 4}$ ).

These results indicate that, contrary to popular belief, drugs that sedate or that impair postural control are not important factors in fractures of the femoral neck. The results are consistent with the hypothesis that the hypocalciuria induced by thiazides protects against fracture, but the degree of protection is not significantly greater than that associated with other drugs.

\section{Introduction}

Several British studies have found that the incidence of fractures of the femoral neck in the United Kingdom is increasing at a much greater rate than can be accounted for by the increasing numbers of elderly people..$^{1-3}$ Though osteoporosis is regarded as being the most important risk factor, the relation between severity of osteoporosis and risk of fracture is controversial. ${ }^{4}$ No change in other risk factors has been shown to account for the increase, but one study implicated use of barbiturates and others have suggested that thiazide diuretics might be protective. ${ }^{5-7}$ We therefore carried out a case-control study to investigate whether fracture of the femoral neck is associated with the use of various drugs that might disturb postural stability and increase any tendency to fall or might modify the development of osteoporosis. 


\section{Patients and methods}

All patients who had undergone surgery for fractures of the femoral neck at the University Hospital, Nottingham, from 1 April to 30 September 1984 were identified from operating theatre records. Of 227 patients identified who were aged over 60,142 lived within $10 \mathrm{~km}$ of the hospital and were therefore considered to be eligible for inclusion in the study. We selected controls by visiting an index patient's general practice and, having confirmed that that patient's records were available, taking the next two records whose subject was of the same sex and age within four years.

\section{Results}

Altogether 142 patients aged over 60 with fractures of the femoral neck were identified from theatre records. In 27 cases the general practitioner was not recorded in the hospital notes, in six the general practitioner refused permission to examine the records, and in seven no records could be found. The remaining 102 patients formed the series of cases (table I). These patients were receiving significantly fewer prescribed drugs than the controls both at the time of fracture and at all points considered in the year before fracture. This was true for each of the three age groups considered

TABLE I-Exposure to prescribed drugs by time before fracture, age, and sex

\begin{tabular}{|c|c|c|c|c|}
\hline & $\begin{array}{c}\text { Patients with } \\
\text { fracture }(n=102)\end{array}$ & $\begin{array}{l}\text { Controls } \\
(n=204)\end{array}$ & $\begin{array}{l}\text { Relative } \\
\text { risk }\end{array}$ & $\begin{array}{l}\text { 95\% Confidence } \\
\text { limits }\end{array}$ \\
\hline $\begin{array}{l}\text { No of men: women } \\
\text { Mean age (years) }\end{array}$ & $\begin{array}{l}12: 90 \\
79 \cdot 1\end{array}$ & $\begin{array}{l}24: 180 \\
78 \cdot 3\end{array}$ & & \\
\hline \multicolumn{5}{|c|}{ No taking prescribed drugs } \\
\hline $\begin{array}{l}\text { At time of fracture } \\
3 \text { Months before fracture } \\
6 \text { Months before fracture } \\
9 \text { Months before fracture } \\
12 \text { Months before fracture }\end{array}$ & $\begin{array}{l}41 \\
40 \\
38 \\
41 \\
38\end{array}$ & $\begin{array}{l}126 \\
122 \\
121 \\
124 \\
110\end{array}$ & $\begin{array}{l}0.42 \\
0.43 \\
0.41 \\
0.43 \\
0.51\end{array}$ & $\begin{array}{l}0 \cdot 26,0 \cdot 67 \\
0 \cdot 27,0 \cdot 70 \\
0 \cdot 25,0 \cdot 60 \\
0 \cdot 27,0 \cdot 70 \\
0 \cdot 31,0 \cdot 82\end{array}$ \\
\hline $\begin{array}{l}\text { By age (years): } \\
60-74 \\
75-84 \\
85+\end{array}$ & $\begin{array}{l}14 \\
14 \\
13\end{array}$ & $\begin{array}{l}40 \\
54 \\
31\end{array}$ & $\begin{array}{l}0.58 \\
0.30 \\
0.50\end{array}$ & $\begin{array}{l}0 \cdot 25,01 \cdot 4 \\
0 \cdot 14,0 \cdot 63 \\
0 \cdot 20,1 \cdot 3\end{array}$ \\
\hline $\begin{array}{l}\text { By sex: } \\
\text { Men } \\
\text { Women }\end{array}$ & $\begin{array}{r}5 \\
36\end{array}$ & $\begin{array}{r}11 \\
114\end{array}$ & $\begin{array}{l}0.84 \\
0.39\end{array}$ & $\begin{array}{l}0.21,3.4 \\
0.23,0.65\end{array}$ \\
\hline
\end{tabular}

TABLE II-Number of drugs prescribed to patients with fracture and controls at time of fracture

\begin{tabular}{lcccccc}
\hline \multicolumn{7}{c}{ No of drugs prescribed } \\
& 0 & 1 & 2 & 3 & 4 & 5 or more \\
\hline Patients with fracture & 61 & 10 & 14 & 9 & 4 & 4 \\
Controls & 78 & 28 & 37 & 33 & 23 & 5 \\
Relative risk & 1.0 & 0.46 & 0.48 & 0.35 & 0.22 & 1.02 \\
$95 \%$ Confidence limits & & $1.00,0.21$ & $0.97,0.24$ & $0.77,0.16$ & $0.63,0.08$ & $3.97,0.26$ \\
\hline
\end{tabular}

$\chi^{2}=15 \cdot 89,5 \mathrm{df}, \mathrm{p}<0 \cdot 01$.

TABLE III-Exposure to drugs at time of fracture

\begin{tabular}{|c|c|c|c|c|c|}
\hline Drug class & $\begin{array}{c}\text { Patients } \\
\text { with fracture } \\
(\mathrm{n}=102)\end{array}$ & $\begin{array}{l}\text { Controls } \\
(n=204)\end{array}$ & $\begin{array}{l}\text { Relative } \\
\text { risk }\end{array}$ & $\begin{array}{l}95 \% \text { Confidence } \\
\text { limits }\end{array}$ & Significance \\
\hline $\begin{array}{l}\text { Any drug } \\
\text { Gastrointestinal drugs } \\
\text { Diuretics } \\
\text { Other cardiovascular drugs } \\
\text { Hypotensive drugs } \\
\text { Hypnotics or sedatives } \\
\text { Non-steroidal anti-inflammatory drugs } \\
\text { Psychotropic agents } \\
\text { Analgesics } \\
\text { Steroids } \\
\text { Antibiotics } \\
\text { Drugs not elsewhere classified } \dagger\end{array}$ & $\begin{array}{r}41 \\
3 \\
13 \\
4 \\
3 \\
3 \\
17 \\
9 \\
12 \\
8 \\
1 \\
4 \\
22\end{array}$ & $\begin{array}{r}126 \\
22 \\
57 \\
18 \\
13 \\
55 \\
31 \\
28 \\
18 \\
2 \\
3 \\
57\end{array}$ & $\begin{array}{l}0.42 \\
0 \cdot 25 \\
0 \cdot 38 \\
0 \cdot 42 \\
0 \cdot 46 \\
0.54 \\
0.54 \\
0.84 \\
0.88 \\
1.00 \\
2 \cdot 74 \\
0.68\end{array}$ & $\begin{array}{l}0 \cdot 26,0 \cdot 67 \\
0 \cdot 08,0 \cdot 79 \\
0 \cdot 20,0 \cdot 72 \\
0 \cdot 14,1 \cdot 24 \\
0 \cdot 13,1 \cdot 55 \\
0 \cdot 30,1 \cdot 00 \\
0 \cdot 25,1 \cdot 17 \\
0 \cdot 41,1 \cdot 73 \\
0 \cdot 37,2 \cdot 10 \\
1 \cdot 00,1 \cdot 00 \\
0 \cdot 64,11 \cdot 76 \\
0 \cdot 39,1 \cdot 18\end{array}$ & $\begin{array}{l}\mathrm{p}=0.0006 \\
\mathrm{p}=0.024 \\
\mathrm{p}=0.0034 \\
\text { NS } \\
\text { NS } \\
\text { NS } \\
\text { NS } \\
\text { NS } \\
\text { NS } \\
\text { NS } \\
\text { NS } \\
\text { NS }\end{array}$ \\
\hline
\end{tabular}

ॠNot including hypotensives.

†Including cytotoxic agents, vitamin and mineral supplements, expectorants, and topical agents.

Altogether $162(57 \%)$ of the controls were matched for age to within one year. All drugs prescribed in the year before the date of the fracture of the femoral neck were noted from the records for the index case and both controls. For each triplet of case and controls dates and durations of prescriptions were converted into weeks of treatment in that year. Hence we could make cross sectional comparisons of drugs prescribed to cases and controls.

Conventional statistical methods were used for analysis. The relative risks quoted are Mantel-Haenszel estimates with confidence limits calculated using Miettinen's method. For the more important drugs groups matched and unmatched analyses were performed, but as there were no significant differences between them only the results of the unmatched analyses are quoted. and for each sex, although the negative association was weaker in men, the number of men with fractures being small. When the number of drugs prescribed to each subject was analysed using the Mantel-Haenszel test for several exposure levels (table II) the tendency for the patients with fractures to have received fewer prescriptions than the controls was significant for all but those receiving five or more drugs. This was true at the time of fracture and at all times in the year before fracture.

The negative association between fracture and drug use held for all major drug classes except antibiotics (table III), and the relative risks associated with each drug class were similar at each three month point in the year preceding fracture. Of those taking diuretics, six patients with fractures and 37 controls were receiving thiazides either alone (31) or in combination with amiloride (12), resulting in a relative risk for use of thiazides of $0.28(95 \%$ 
confidence limits $0 \cdot 12,0.66 ; \mathrm{p}=0.004)$. The remaining seven patients with fractures and 20 controls were receiving loop diuretics such as frusemide (19) with a relative risk of fracture of $0.68(95 \%$ confidence limits $0.28,1 \cdot 7)$. A positive association with antibiotics was significant only at three months before fracture, when nine patients with fractures and two controls were receiving antibiotics (relative risk $=9 \cdot 8 ; \mathrm{p}=0 \cdot 0023$ ).

According to the records, 61 patients sustained a cervical type of fracture and 35 cases a trochanteric type; in six cases the type was not stated. The negative association with drugs prescribed applied to both cervical fractures (relative risk $=0.52 ; 95 \%$ confidence limits $0.28,0.96$ ) and trochanteric fractures (relative risk $=0.30 ; 95 \%$ confidence limits $0.13,0.69$ ). The negative association between diuretics prescribed and fracture persisted when the cases were separated according to type of fracture (cervical: relative risk $=0 \cdot 47$; trochanteric: relative risk $=0 \cdot 37$ ) but did not retain significance. Further analyses by drug classes were limited by small numbers.

\section{Discussion}

Might these unexpected results be due to bias in the selection of cases and controls or in obtaining the drug histories? The case series was derived from all patients with fracture of the femoral neck from a defined area attending over six months. It is difficult to see how the small number $(<10 \%)$ of patients dying early or not having surgery might have produced substantial bias. There is no ideal way of monitoring drug usage. Interviewing elderly patients who have recently sustained a fracture of the femoral neck presents obvious problems, and in this study comparison of the drug histories in the hospital records with the histories in the general practice records confirmed considerable under-recording. Drug histories obtained from general practice records are unaffected by bias in recall, and any under-recording of drugs prescribed should affect cases and controls equally. As far as we could determine there was no bias in our examination of the general practice records, and as we had originally expected increased drug prescribing to patients with fractures any undetected bias should have had a conservative effect. The finding that $62 \%$ of controls were taking at least one prescribed drug accords with other estimates: according to the General Household Survey $56 \%$ of women aged $65-74$ and $67 \%$ of those aged 75 and over are receiving at least one prescribed drug. ${ }^{8}$ Furthermore, our estimates of drug taking by the controls are similar to those in a recent study of acute gastrointestinal bleeding and drug taking in Nottingham, in which 200 controls were selected in the same way and interviewed. In that study $75 \%$ were taking at least one drug, $21 \%$ were taking diuretics, $16 \%$ were taking non-steroidal anti-inflammatory drugs, and none were taking oral steroids. ${ }^{9}$

As there do not seem to be any serious biases how might our results be explained? It is difficult to see how drug taking in general could be directly protective. On the other hand, drug taking probably reflects health, and consumption of drugs such as laxatives, antacids, and benzodiazepines may reflect perceived as much as real ill health; one possible explanation, therefore, is that before their injury most patients with fracture of the femoral neck either are fitter or regard themselves as fitter than their peers. Consequently they are more active and at greater risk of falling badly enough to sustain a fracture.

There have been few studies of drug usage preceding fracture of the femoral neck. One study, also from Nottingham, found that the prevalence of barbiturate use in a group of patients with such fractures attending a rehabilitation unit was $26 \%$ with an overall $83 \%$ of patients taking some type of hypnotic. ${ }^{5}$ These figures, however, were lower than the prevalences of barbiturate use $(46 \%)$ and hypnotic use $(91 \%)$ found in a comparison group of geriatric outpatients, and a subsequent study from Nottingham found that only $4 \%$ of patients with fractures of the femoral neck were taking barbiturates. ${ }^{10}$ Another study reported that $17 \%$ of selected patients with fractures of the femoral neck were taking corticosteroids and $19 \%$ were taking anticonvulsants, ${ }^{11}$ but it is questionable whether studies of selected cases are generally applicable. Our results are consistent with another study that took controls from the community: after interviewing 184 women with fracture of the femoral neck and 97 controls matched for age Baker could find no association between taking drugs, including hypnotics and steroids, and sustaining a fracture. ${ }^{12}$ In keeping with our findings a recent survey of elderly Americans taking thiazides and other hypotensive drugs found that, though symptoms of dizziness, fainting, and blacking out were more common in women taking these drugs, only $7 \cdot 7 \%$ of women taking thiazides reported previous fractures compared with $11 \cdot 3 \%$ of women not taking hypotensive drugs. ${ }^{7}$ This has been regarded as circumstantial evidence that thiazides, by reducing urinary calcium loss and increasing bone mineralisation, protect against fracture of the femoral neck. The relative risk of 0.28 associated with use of thiazides in this study, though lower than the risk associated with several other drug classes, is similar to that for drugs acting on the gastrointestinal tract. Subsequent studies should determine whether the apparent protective effect of thiazides is drug specific and not related to drug taking in general.

Much of the research on the aetiology of fracture of the femoral neck has rightly concerned the role of osteoporosis, but osteoporosis is endemic among elderly women and when an allowance is made for age the correlation between severity of osteoporosis and the risk of fracture is not strong. ${ }^{6}$ When other potential risk factors are taken into consideration the importance of falls and factors affecting postural stability appears to have been accepted without much evidence. This study indicates that drugs that can impair postural stability are not associated with fractures of the femoral neck and that some even seem to be protective. Our hypothesis that less drug taking by patients who sustain such fractures reflects better real or perceived health, greater mobility and activity, and hence greater exposure to the possibility of fracture seems plausible and should be fairly easy to test.

We acknowledge the help of Dr L Hall, Dr M A Varnam, and the other Nottingham general practitioners without whose cooperation this study would not have been possible. We also thank Professor J M Elwood and Dr J C G Pearson for advice and criticism.

\section{References}

1 Lewis AF. Fracture of the neck of the femur: changing incidence. $\mathrm{Br}$ Med $\mathcal{O}$ 1981;283:1217-20 2 Wallace WA. The increasing incidence of fractures of the proximal femur: an orthopaedic epidemic. Lancet 1983;i:1413-4.

3 Boyce WJ, Vessey MP. Rising incidence of fracture of the proximal femur. Lancet 1985; i: 150-1 4 Aitken JM. Relevance of osteoporosis in women with fracture of the femoral neck. Br Med $\mathcal{J}$ 1984;288:597-601.

5 MacDonald JB, MacDonald ET. Nocturnal femoral fracture and continuing widespread use of barbiturate hypnotics. Br Med $\mathcal{J}$ 1977;ii:483-5.

6 Wasnich RD, Benfante RJ, Yano K, et al. Thiazide effect on the mineral content of bone. N EnglJ Med 1983;309:344-7.

7 Hale WE, Steward RB, Marks RG. Central nervous system symptoms of elderly subjects using antihypertensive drugs. 7 Am Geriatr Soc 1984;32:5-10.

8 Office of Population Censuses and Surveys. General household survey 1978. London: HMSO, 1980.

9 Somerville KW, Faulkner G, Langman MJS. Non-steroidal anti-inflammatory drugs and bleeding peptic ulcer. Lancet 1986;i:464-7.

10 Sloan J, Holloway G. Fractured neck of the femur: the cause of the fall? Injury 1981;13:230-2. 11 Muckle DS. Iatrogenic factors in femoral neck fracture. Injury 1981;8:98-101.

12 Baker MR. The epidemiology and aetiology of femoral neck fracture. Newcastle upon Tyne: University of Newcastle upon Tyne 1980. (MD thesis.)

(Accepted 4 February 1986) 